\title{
Reduction of aerobic and lactic acid bacteria in dairy desludge using an integrated compressed $\mathrm{CO}_{2}$ and ultrasonic process
}

\author{
Tim W. Overton ${ }^{1,2}$ - Tiejun Lu ${ }^{1}$ - Narinder Bains ${ }^{3}$. \\ Gary A. Leeke ${ }^{1}$
}

Received: 31 January 2015 /Revised: 11 June 2015 / Accepted: 15 June 2015 /

Published online: 10 July 2015

(C) INRA and Springer-Verlag France 2015. This article is published with open access at Springerlink.com

\begin{abstract}
Current treatment routes are not suitable to reduce and stabilise bacterial content in some dairy process streams such as separator and bactofuge desludges which currently present a major emission problem faced by dairy producers. In this study, a novel method for the processing of desludge was developed. The new method, elevated pressure sonication (EPS), uses a combination of low frequency ultrasound $(20 \mathrm{kHz})$ and elevated $\mathrm{CO}_{2}$ pressure (50 to 100 bar). Process conditions (pressure, sonicator power, processing time) were optimised for batch and continuous EPS processes to reduce viable numbers of aerobic and lactic acid bacteria in bactofuge desludge by $\geq 3-\log$ fold. Coagulation of proteins present in the desludge also occurred, causing separation of solid (curd) and liquid (whey) fractions. The proposed process offers a 10-fold reduction in energy compared to high temperature short time (HTST) treatment of milk.
\end{abstract}

Keywords Desludge $\cdot$ Milk byproduct processing $\cdot$ Sonication $\cdot$ Pressure $\cdot$ Supercritical

\section{Introduction}

There are a number of treatments commonly applied to reduce the viability of bacteria in raw milk to generate products fit for human consumption. Fresh milk is commonly

This paper is part of the Special issue dedicated to the 9th International Cheese Symposium held in Cork, Ireland and organized by Teagasc in collaboration with University College Cork and INRA, 12th \& 13th November 2014.

Gary A. Leeke

G.A.Leeke@bham.ac.uk

1 School of Chemical Engineering, University of Birmingham, Edgbaston, Birmingham B15 2TT, UK

2 Institute of Microbiology \& Infection, University of Birmingham, Edgbaston, Birmingham B15 2TT, UK

3 Sere-Tech Innovation Ltd., Sutton Coldfield, Birmingham B74 2AD, UK 
pasteurised using a continuous high temperature short time (HTST) pasteurisation process, typically $72{ }^{\circ} \mathrm{C}$ for $\geq 15 \mathrm{~s}$, or sterilised using an ultra-high temperature treatment (UHT; $150{ }^{\circ} \mathrm{C}$ for $1 \mathrm{~s}$ ). Alternative routes of bacterial deactivation or removal from dairy streams, either industrially or in academic research settings, include centrifugation/bactofugation, reduction in $\mathrm{pH}$ (in casein manufacture), sonication, pulsed electric fields and high pressure treatments, each of which have different impacts on the microbiological safety and chemical and sensory properties of the product (Sampedro et al. 2005; Ortega-Rivas and Salmerón-Ochoa 2014). These techniques are typically used in combination to reduce viability of spoilage and pathogenic bacteria to acceptable limits in the final product. Many of the above processes typically require high energy inputs (Pereira and Vicente 2010) or require additional downstream separation processes (for example removal of organic or mineral acids in casein coagulation). Rapid decompression treatment has also been reported in the literature (Foster et al. 1962; Fraser 1951; Hemmingsen and Hemmingsen 1980), but this is only suitable for bacteria that contain gas vacuoles and is therefore not broadly applicable for food processing.

However, many of these treatment routes are not suitable to reduce the bacterial content in some process streams found in the dairy industries. Desludge streams generated by the bactofuge (containing large numbers of bacteria) and separator (containing particles even heavier than the skim, such as sediment, somatic cells and some bacteria) cannot be treated by thermal routes and are currently disposed of at high cost to the processor. A large milk processing site can produce up to $15,000 \mathrm{~L} \cdot \mathrm{day}^{-1}$ of desludge which is disposed of through water dilution and discharged to sewer at costs of between US\$150 k and US\$1.5 M per annum in effluent discharge. In light of this, UK dairy producers have tried local initiatives to treat the desludge; however, several challenges have arisen: bacterially and thermally induced solidification of the desludge, classification of the desludge as waste as it is not effectively pasteurised or heat treated, high off-site waste disposal costs, high transport costs and high tanker cleaning costs.

In this paper, we describe the development of elevated pressure sonication (EPS), a novel technology for the treatment of desludges (Bains and Leeke 2015). The technique uses a combination of elevated $\mathrm{CO}_{2}$ pressure (up to 100 bar; lower than high pressure and rapid decompression treatments) and relatively low frequency sonication $(20 \mathrm{kHz}$ as opposed to 18 to $500 \mathrm{MHz}$ commonly used in other antibacterial processes). We optimised process parameters (sonicator power, pressure, process time, temperature) to maximise reduction of viable aerobic and lactic acid bacterial counts. The process was optimised in both batch and continuous modes.

\section{Materials and methods}

\subsection{Materials}

Bactofuge and separator desludges were supplied by a leading dairy company. Samples were collected, stored at $4{ }^{\circ} \mathrm{C}$ and used within $24 \mathrm{~h}$ of collection; after this time, the bactofuge desludge had phase separated and resultant solids led to blockage of the pump inlet. $\mathrm{CO}_{2}$ and $\mathrm{N}_{2}$ were obtained from BOC (Wolverhampton, UK) and had given purities of $99.8 \% v / v$ and $99.998 \%$, respectively. 


\subsection{Batch tests}

A schematic of the experimental setup used for the high pressure sonication is shown in Fig. 1a. The vessel was a 1-L stainless steel reactor modified for ultrasound (Parr, USA; maximum working conditions $350{ }^{\circ} \mathrm{C}, 200$ bar), with heating jacket, temperature control and thermowell. An ultrasound probe (Sonics and Materials, USA) was integrated into the vessel head and sealed to maintain the pressure at the operating conditions. Although not mechanically agitated, the ultrasound probe allowed sufficient dispersion of the gas with the desludge, as validated by Cenci et al. (2014). Then, $700 \mathrm{~mL}$ of desludge was charged into the vessel, which resulted in the probe tip being immersed in the desludge to a depth of $2 \mathrm{~mm}$, and the headspace and ancillaries were evacuated using the gas of choice $\left(\mathrm{CO}_{2}\right.$ or $\left.\mathrm{N}_{2}\right)$. The pressure and temperature were then raised to the desired conditions. Sonication was introduced using pulsed mode ( $1 \mathrm{~s}$ on, $1 \mathrm{~s}$ off) for the desired time at $20 \mathrm{kHz}$ at different percentages of power $(1500 \mathrm{~W}=100 \%$ power $)$. The internal pressure was observed using a transducer connected to a display (Druck, Leicester, UK) to within \pm 0.1 bar, while the internal temperature was measured using a type-K thermocouple to within $\pm 0.1^{\circ} \mathrm{C}$. Following the experiment, the solid (curd) and liquid (whey) fractions were collected and analysed for cell viability. For decontamination, the vessel was heated to $125^{\circ} \mathrm{C}$ for $30 \mathrm{~min}$ and then washed with Virkon (DuPont, Stevenage, UK) to minimise cell contamination between tests.

\subsection{Continuous flow apparatus}

A similar setup to batch was used for the continuous flow tests. A schematic of the process is shown in Fig. $1 \mathrm{~b}$ and consists of three sections, (1) product/gas contact, (2) sonication chamber and (3) separator. In (1), the product and gas $\left(\mathrm{CO}_{2}\right.$ or $\left.\mathrm{N}_{2}\right)$ were pumped into a stainless steel static mixer where they were contacted. A diaphragm pump (LEWA LDB M9, GmbH) was used for delivering desludge samples into the sonication chamber. Inside the sonication chamber (2) the bacteria present in the product stream were subjected to relatively low frequency sonication $(20 \mathrm{kHz})$.

a

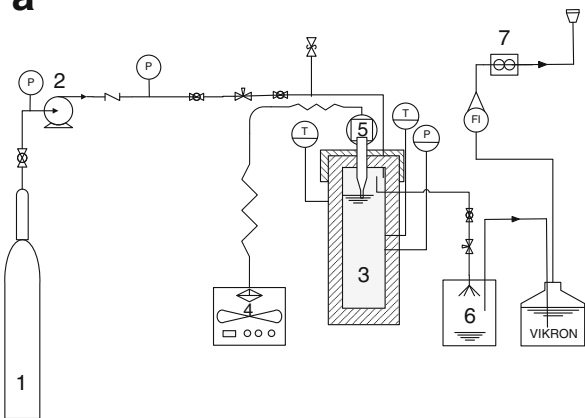

b



Fig. 1 Schematic of experimental setup. a Elevated pressure sonication batch tests. 1 gas cylinder, 2 pump, 3 high pressure vessel, 4 ultrasonic controller, 5 ultrasonic probe, 6 collection vessel, 7 mass flow meter. b Continuous flow experimental setup. Section 1 =product/gas contact; Section 2 =high pressure sonication chamber; Section $3=$ separation 
Sonication was provided by a Sonics VCX130 Ultrasonic Processor connected to a 1/4-inch solid Titanium Alloy Probe to give a maximum power output of $130 \mathrm{~W}$. Typical residence times were $30 \mathrm{~s}$ to $1 \mathrm{~min}$. The product left the chamber and entered the separation vessel (3) where the solid fraction was separated by gravity from the liquid fraction. The liquid fraction was removed over the weir plates for analysis. The gas disengaged from the liquid and could be vented or recycled. There will be a small amount of gas in the liquid phase which could either be vented (and recycled) or, depending on its use, kept within the liquid. The solid fraction can be periodically removed from the separation vessel using a rotating valve. Desludge is typically produced at the dairy at $50{ }^{\circ} \mathrm{C}$ and this temperature was largely used; however, lower temperatures were also evaluated.

\subsection{Bacteria viability tests}

Bacterial counts were performed on desludge samples before and after processing to generate bacterial deactivation data. Samples were serially diluted in sterile maximum recovery diluent (MRD; $8.5 \mathrm{~g} \cdot \mathrm{L}^{-1} \mathrm{NaCl}$ and $1 \mathrm{~g} \cdot \mathrm{L}^{-1}$ tryptone in distilled water) and plated onto nutrient agar (Oxoid, Basingstoke, UK; for enumerating total aerobic viable count) or MRS (de Man, Rogosa, Sharpe) agar (Oxoid; for enumerating lactic acid bacteria). Nutrient agar plates were incubated aerobically for $24-48 \mathrm{~h}$ at $37{ }^{\circ} \mathrm{C}$ and $\mathrm{MRS}$ agar plates were incubated in candle jars (microaerobic environment with decreased $\mathrm{O}_{2}$ and elevated $\mathrm{CO}_{2}$ level) for $24-72 \mathrm{~h}$ at $30{ }^{\circ} \mathrm{C}$ prior to counting. For analysis of bacterial content of curd samples, fresh wet curd obtained after batch processing was weighed, added to $100 \mathrm{~mL}$ of water and stomached using a Seward 400 Circulator Stomacher at $200 \mathrm{rpm}$ for $5 \mathrm{~min}$ before serial dilution and plating as above.

\subsection{Chemical analysis methods}

The Rose Gottlieb method (the standard method of ISO, FAO and WHO for milk fat content measurement) was used to determine the fat content $\left(\mathrm{mg} \cdot 100 \mathrm{~mL}^{-1}\right)$ in desludge before and after treatment (AOAC 2000; Official method 905.02). Hexane was used to replace petroleum ether.

A MaxSignal ${ }^{\circledR}$ No-Mel Milk Test Kit (Bioo Scientific, Austin, TX) was used to measure protein content in liquid samples before and after treatment. The standard curve was obtained using UV on-line detection using standards provided in the test kit. This kit was not suitable for solid samples, which were sent for analysis at an independent accredited laboratory (Butterworths, London, UK). The classic Kjeldahl method was used in accordance with USP 35,461 Method 1 to determine the nitrogen content in a sample which was then converted into protein content. Liquid samples were also sent to them for comparison with our results.

COD reagent (Merck Millipore Spectroquant) with concentration range of 500 $10,000 \mathrm{mg} \cdot \mathrm{L}^{-1}$ was used to measure the COD (chemical oxygen demand) of liquid samples before and after treatment. 


\section{Results and discussion}

\subsection{Batch processing of bactofuge desludge}

Power sonication is a technique used to pasteurise many dairy products (BermúdezAguirre and Barbosa-Cánovas 2011); however, it is used at high frequency (typically 18 to $500 \mathrm{MHz}$ ) to kill bacteria to acceptable limits. Sonication causes cycles of compression and expansion as well as cavitation in microbial cells. The implosion of bubbles generates points with very high temperatures and pressures which are able to inactivate cells. Sonication is most effective when combined with other microbiological control measures as smaller microbial cells are often more resistant to this treatment (Geciova et al. 2002). One such combination is thermosonication which is undertaken at temperatures between 80 and $95{ }^{\circ} \mathrm{C}$. However, since bactofuge desludge is periodically discharged during dairy processing at $50{ }^{\circ} \mathrm{C}$, this technique would be economically unviable due to the energy input needed to raise the temperature. In addition, processing desludge at high temperatures also results in solidification to a latex-like product which cannot flow and would therefore lead to blockages in an industrial process.

In light of the above, lower frequency sonication $(20 \mathrm{kHz})$ was tested in combination with gases at elevated pressures to investigate their effect on the viable cell count of aerobic and lactic acid bacteria in desludge. Lower frequency sonication has lower energy input than the power sonication techniques described above. A series of batch tests were undertaken on bactofuge desludge using the apparatus shown in Fig. 1a and different process conditions (Figs. 2 and 3).

\subsection{Effect of sonication power, pressure and processing time on viable cell counts}

The sonication power was varied from 1500 to $150 \mathrm{~W}$ at a $\mathrm{CO}_{2}$ pressure of $100 \mathrm{bar}$ and a processing temperature of $50{ }^{\circ} \mathrm{C}$ (Fig. $2 \mathrm{a}, \mathrm{b}$ ). The sonication power could be reduced to $150 \mathrm{~W}$ and a 3 to $3.5 \log$ reduction in viable cell count for both aerobic and lactic acid bacteria could still be obtained. Viable cell counts for samples at 300, 450 and $750 \mathrm{~W}$ sonication power were undertaken up to 2 and 3 days post-processing. The results demonstrate the effectiveness of the combined treatment to stabilise cell count levels. It is evident that the kill rate of aerobic bacteria is better than that for lactic acid bacteria.

The aerobic and lactic acid bacteria counts were repeated for some tests and were found to have a $\mathrm{ST}_{\mathrm{DEV}}$ of $11 \%$ for aerobic bacteria and a $\mathrm{ST}_{\mathrm{DEV}}$ of $21 \%$ for lactic acid bacteria. The reproducibility of aerobic bacteria is better than for lactic acid bacteria although both are within an acceptable experimental error.

In light of the results shown in Fig. 2a and b, tests were undertaken at lower pressure in order to reduce the pressure design requirements for the treatment process. Figure $2 \mathrm{c}$ and $d$ shows that a pressure $\geq 50$ bar was required to achieve a 3.5-log-fold reduction in aerobic viable cell count levels, whereas a pressure $\geq 100$ bar was required to achieve a 3.5-log-fold reduction in lactic acid viable cell count levels. In the absence of any gas pressure ( 0 bar, ambient pressure conditions), sonication had a small effect on viable cell count with approximately $1-\log$-fold reduction in both total aerobic and LAB counts. The combination of $\mathrm{CO}_{2}$ and sonication is therefore necessary for the process to be effective.

The effect of sonication time was investigated in order to reduce the energy requirement and processing time of the treatment process. Figure 3 shows that the time 




Before processing $\square$ After processing
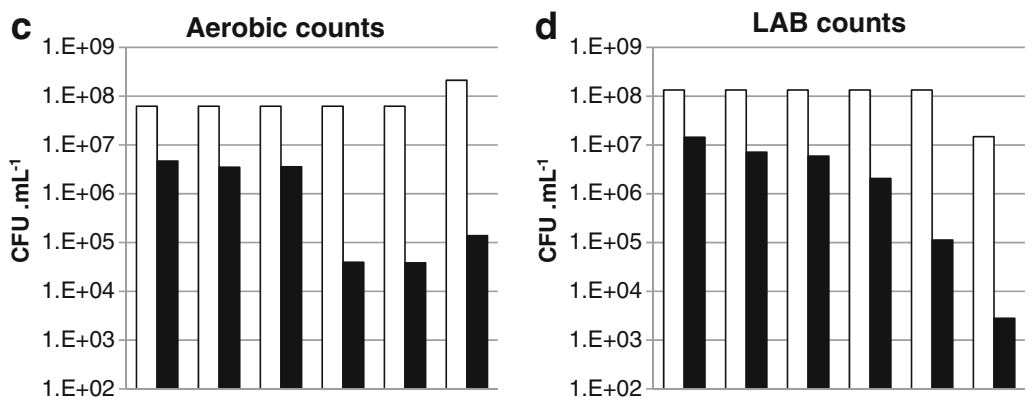

\begin{tabular}{|c|c|c|c|c|c|c|c|c|c|c|c|c|}
\hline $\mathrm{CO}_{2}$ Pressure (bar) & 0 & 10 & 20 & 50 & 100 & 100 & 0 & 10 & 20 & 50 & 100 & 100 \\
\hline Sonicator power (W) & \multicolumn{5}{|c|}{750} & 1500 & \multicolumn{5}{|c|}{750} & 1500 \\
\hline Temperature $\left({ }^{\circ} \mathrm{C}\right)$ & \multicolumn{6}{|c|}{50} & \multicolumn{6}{|c|}{50} \\
\hline Time (min) & \multicolumn{5}{|c|}{60} & 15 & \multicolumn{5}{|c|}{60} & 15 \\
\hline
\end{tabular}

Fig. 2 Effect of sonication power (a, b) and pressure (c, d) on viable aerobic (a, c) and lactic acid (b, d) bacterial counts in bactofuge desludge before and after batch EPS processing. White bars, before processing; black bars, after processing

could be reduced to 1 min with 3-log-fold reductions in viable cell counts still being achieved. The sonication time was further reduced to $0.5 \mathrm{~min}$ (with all other conditions the same) and showed favourable results toward cell death ( 3.4-log-fold reduction in aerobic counts, $\sim 3.1-\log$-fold reduction in LABs). This short process time makes the EPS treatment process potentially suitable for continuous processing of desludge. Tests were also undertaken in the presence of $\mathrm{N}_{2}$ at 100 bar instead of $\mathrm{CO}_{2}$. The results show that $\mathrm{N}_{2}$ had an insignificant effect on cell viability, demonstrating that $\mathrm{CO}_{2}$ was required for process effectiveness.

\subsection{Characteristics of processed desludge}

Photographs of untreated and treated bactofuge desludge are shown in Fig. 4. Due to the relatively low temperature, frequency of the sonication and power input, the solid fraction did not form a latex-like material following processing and exhibited the ability to flow due to the presence of the liquid phase. During exposure to high pressure $\mathrm{CO}_{2}$, the $\mathrm{pH}$ in the desludge would have been reduced to approximately 3 at the process 


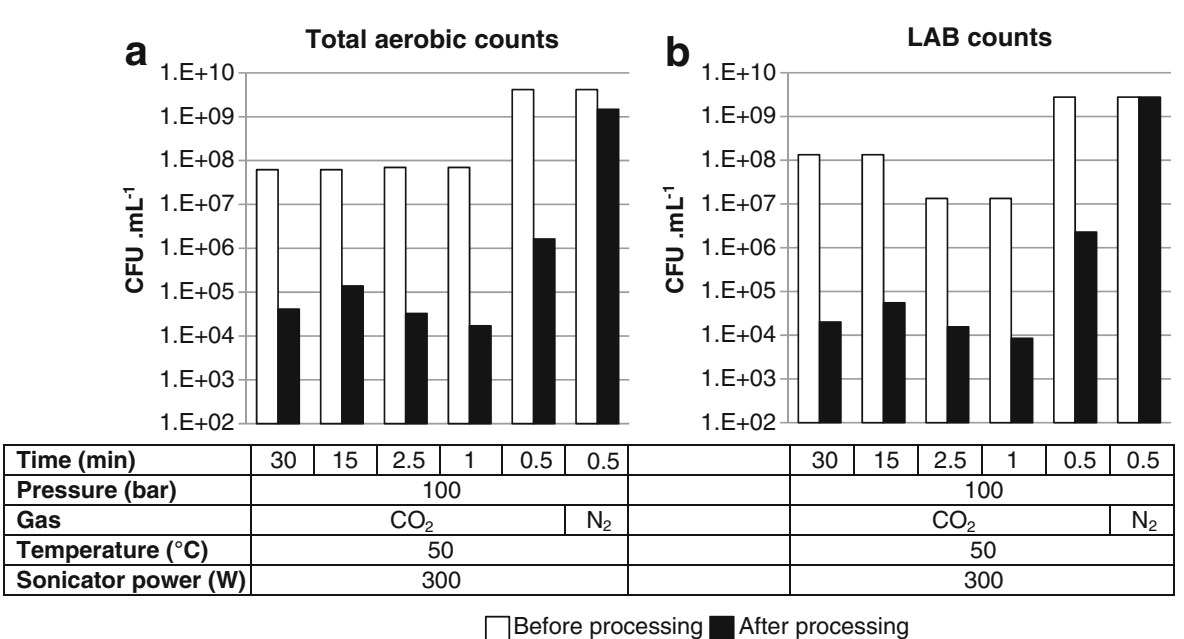

Fig. 3 Effect of sonication time and gas on viable aerobic (a) and lactic acid (b) bacterial counts in bactofuge desludge before and after batch EPS processing. White bars, before processing; black bars, after processing

conditions (Leeke et al. 2005). The literature reports that when sonication is combined with a low pH environment, organisms are not able to grow (Bermúdez-Aguirre and Barbosa-Cánovas 2011). It is thought that the combination of sonication, pressure and lowering of $\mathrm{pH}$ results in bacterial death in this process, in a similar manner to the hurdle technology approach used in food processing. The lowered $\mathrm{pH}$ also caused the desludge to separate into liquid (whey) and solid (curd) fractions, without the addition of solid chemicals dissolved in the process liquor. The lack of bacterial killing in the presence of $\mathrm{N}_{2}$ (Fig. 3) may be explained by its lower solubility in water (assumed to be the main liquid component); $1.011 \mathrm{~cm}^{3} \mathrm{STP} \cdot \mathrm{g}^{-1}$ water as opposed to $25.6 \mathrm{~cm}^{3} \mathrm{STP} \cdot \mathrm{g}^{-1}$ water for $\mathrm{CO}_{2}$ at 100 bar and $50{ }^{\circ} \mathrm{C}$ (Wiebe and Gaddy 1939; Wiebe and Gaddy 1940; Wiebe et al. 1933). In addition, the chemical properties of $\mathrm{N}_{2}$ would not lead to a decrease in $\mathrm{pH}$ during processing.

Prior to treatment the COD of the desludge was 1.2 million $\mathrm{mg} \cdot \mathrm{L}^{-1}$ making it costly to dispose of. After high pressure sonication treatment, the COD of the whey fraction was $33,000-42,000 \mathrm{mg} \cdot \mathrm{L}^{-1}$ with the remainder in the solid fraction. Thus, the treatment does not lower the COD but partitions it into the solid fraction. This offers an added advantageous separation process and retains the majority of the COD in a
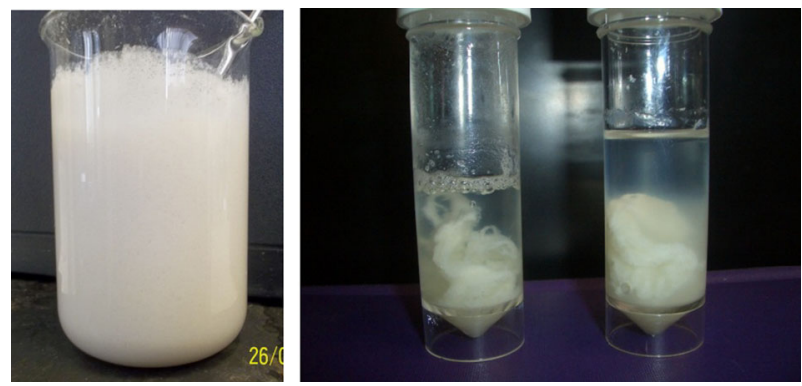

Fig. 4 Images of bactofuge desludge pre- (left) and post- (right) EPS treatment. Process conditions: batch; 100 bar $\mathrm{CO}_{2}, 300 \mathrm{~W}$ pulsed sonication power, $3 \mathrm{~min}$ 
dewatered solid fraction making it suitable for use as a value-added product such as animal feed or an energy source. The whey fraction is also likely to contain valuable components, similar to those found in cheese whey (de Wit 2001).

\subsection{Energy requirements for elevated pressure sonication treatment}

Table 1 shows the energy requirements of the sonicator $\left(\mathrm{kJ} \cdot \mathrm{L}^{-1}\right)$ to treat $700 \mathrm{~mL}$ of bactofuge desludge using the batch EPS process. Selecting test 6 as the optimal case, the additional energy requirements for $\mathrm{CO}_{2}$ compression and desludge compression were calculated as 6.1 and $8.6 \mathrm{~kJ} \cdot \mathrm{L}^{-1}$, respectively, giving the total energy required to process $1 \mathrm{~L}$ of desludge as $24.7 \mathrm{~kJ}$. A comparison is made with the energy required to pasteurise milk using HTST treatment. The EPS process requires less energy than that required to pasteurise milk and is therefore highly attractive as a commercial process.

\subsection{Continuous tests on desludge samples}

Using the optimum batch conditions identified above, the process was modified to treat desludge under continuous flow conditions (Fig. 1b) to test its suitability for large volume processing. Tests were carried out on both bactofuge and separator desludge. Since dairy plants produce similar quantities of separator and bactofuge desludge, a mixture containing 50:50 vol.\% of both desludges was tested using the continuous EPS process (Fig. 5).

Similar to the batch tests (Figs. 2 and 3), lowering the pressure or sonicator energy input resulted in poorer reductions in viable cell numbers. Cell viability was significantly reduced for the separator sample with the flow process giving an even better reduction in viable counts than batch processing, possibly from the enhanced mixing induced in the flow process. In addition, pulsed sonication was also tested. The flow rate of the samples was $\mathrm{kept}$ constant at $10 \mathrm{~mL} \cdot \mathrm{min}^{-1}$ while the sonication was either

Table 1 Energy requirement to treat bactofuge desludge at different conditions

\begin{tabular}{|c|c|c|c|c|c|c|}
\hline \multicolumn{2}{|c|}{ Method/test number } & \multirow{2}{*}{$\begin{array}{l}\begin{array}{l}\text { Pressure } \\
\text { (bar) }\end{array} \\
100\end{array}$} & \multirow{2}{*}{$\begin{array}{l}\text { Temperature } \\
\left({ }^{\circ} \mathrm{C}\right)\end{array}$} & \multirow{2}{*}{$\begin{array}{l}\text { Power } \\
(\mathrm{W}) \\
1500\end{array}$} & \multirow{2}{*}{$\begin{array}{l}\begin{array}{l}\text { Time } \\
(\mathrm{min})\end{array} \\
15\end{array}$} & \multirow{2}{*}{$\begin{array}{l}\begin{array}{l}\text { Energy needed } \\
\left(\mathrm{kJ} \cdot \mathrm{L}^{-1}\right)\end{array} \\
854\end{array}$} \\
\hline EPS & Test 1 & & & & & \\
\hline & Test 2 & 50 & 50 & 750 & 30 & 701 \\
\hline & Test 3 & 100 & 50 & 750 & 30 & 1241 \\
\hline & Test 4 & 100 & 50 & 300 & 15 & 171 \\
\hline & Test 5 & 100 & 50 & 300 & 2.5 & 34 \\
\hline & Test 6 & 100 & 50 & 300 & 1 & 10 \\
\hline \multirow{3}{*}{\multicolumn{2}{|c|}{$\begin{array}{l}\text { Pasteurisation of } \\
\text { milk by HTST }\end{array}$}} & Continuous & 72 & & 0.25 & 196 \\
\hline & & Batch & 63 & & 15 & 158 \\
\hline & & High fat & 75 & & 0.25 & 209 \\
\hline
\end{tabular}

All tests gave a 3- to 3.5-log-fold reduction in total aerobic counts. All tests, except Test 2, gave a 3- to 3.5-logfold reduction in lactic acid bacteria. Energy needed for EPS process based on sonicator energy input only. HTST based on process without heat integration

HTST high temperature short time 

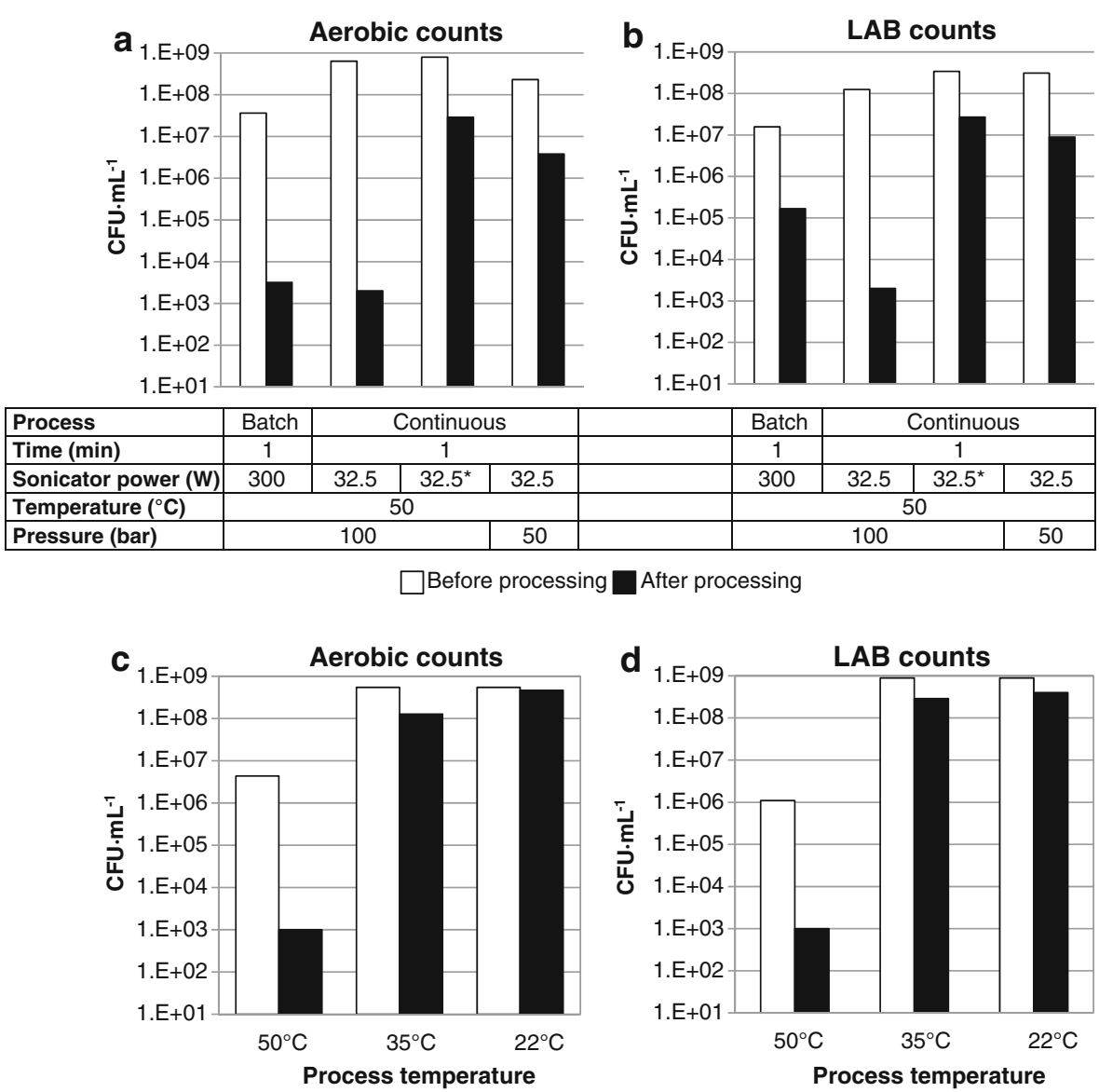

After processing

Fig. 5 a, b The effect of different batch and continuous EPS processing conditions on aerobic (a) and lactic acid (b) bacterial counts. White bars, before processing; black bars, after processing. Batch process was performed on bactofuge desludge (Test 6 in Table 1), continuous process was performed on a 1:1 mixture of bactofuge and separator desludges. Continuous process used flow rates of $10 \mathrm{~mL} \cdot \mathrm{min}^{-1}$ desludge and $\sim 4 \mathrm{~g} \cdot \mathrm{min}^{-1} \mathrm{CO}_{2}$, giving a residence time of $1 \mathrm{~min}$. *Pulsed sonication, $1 \mathrm{~s}$ on and $1 \mathrm{~s}$ off. c, d Effect of processing temperature on aerobic (c) and lactic acid (d) bacterial counts. Process conditions were as follows: continuous process; pressure, 100 bar; temperature, as shown; sonicator power $=32.5 \mathrm{~W}$; sample flow, $10 \mathrm{~mL} \cdot \mathrm{min}^{-1}, \mathrm{CO}_{2}$ flow, $4 \mathrm{~g} \cdot \mathrm{min}^{-1}$

constant $\left(18 \mathrm{~kJ} \cdot \mathrm{L}^{-1}\right.$ energy input) or pulsed modality $\left(11.9 \mathrm{~kJ} \cdot \mathrm{L}^{-1}\right.$ energy input). Temperature $\left(50{ }^{\circ} \mathrm{C}\right)$, pressure $(100 \mathrm{bar})$ and $\mathrm{CO}_{2}$ flow rate $\left(\sim 4 \mathrm{~g} \cdot \mathrm{min}^{-1}\right)$ were the same for both tests. For either continuous or pulsed sonication, aerobic bacterial counts reduced from $4.3 \times 10^{6} \mathrm{CFU} \cdot \mathrm{mL}^{-1}$ before treatment to $<10^{3} \mathrm{CFU} \cdot \mathrm{mL}^{-1}$ after treatment; LAB counts similarly reduced from $1.1 \times 10^{6} \mathrm{CFU} \cdot \mathrm{mL}^{-1}$ before treatment to $<10^{3} \mathrm{CFU} \cdot \mathrm{mL}^{-1}$ after treatment (see Fig $5 \mathrm{c}$ and d).

The effect of temperature on continuous EPS processing of bactofuge desludge was tested. Tests were carried out at 50 and $35{ }^{\circ} \mathrm{C}$ (conditions where $\mathrm{CO}_{2}$ was supercritical) and $22{ }^{\circ} \mathrm{C}$ (where $\mathrm{CO}_{2}$ was liquid). It was discovered that temperature and state play a key role in desludge treatment (Fig. 5c, d). Both liquid $\mathrm{CO}_{2}$ and supercritical $\mathrm{CO}_{2}$ close to the critical point $\left(31^{\circ} \mathrm{C}\right)$ did not effectively kill bacteria. 


\subsection{Shelf-life of treated and untreated bactofuge desludge}

The shelf-life of untreated bactofuge desludge was compared to treated desludge (100 bar $\mathrm{CO}_{2}, 50{ }^{\circ} \mathrm{C}, 32.5 \mathrm{~W}$ power, pulsed, 1 min residence time and energy input of $12 \mathrm{~kJ} \cdot \mathrm{L}^{-1}$ ) in terms of lactic acid and aerobic counts. Treated and untreated samples were incubated at either room temperature or $4{ }^{\circ} \mathrm{C}$ and viable counts determined at daily intervals (Fig. 6a, b). EPS-treated bactofuge desludge could be stored at $4{ }^{\circ} \mathrm{C}$ for 5 days without an obvious increase in LAB counts and with less than 1 log increase in total aerobic counts. The treated sample stored at room temperature attained similar viable counts to the untreated sample after 1-day storage at room temperature. After
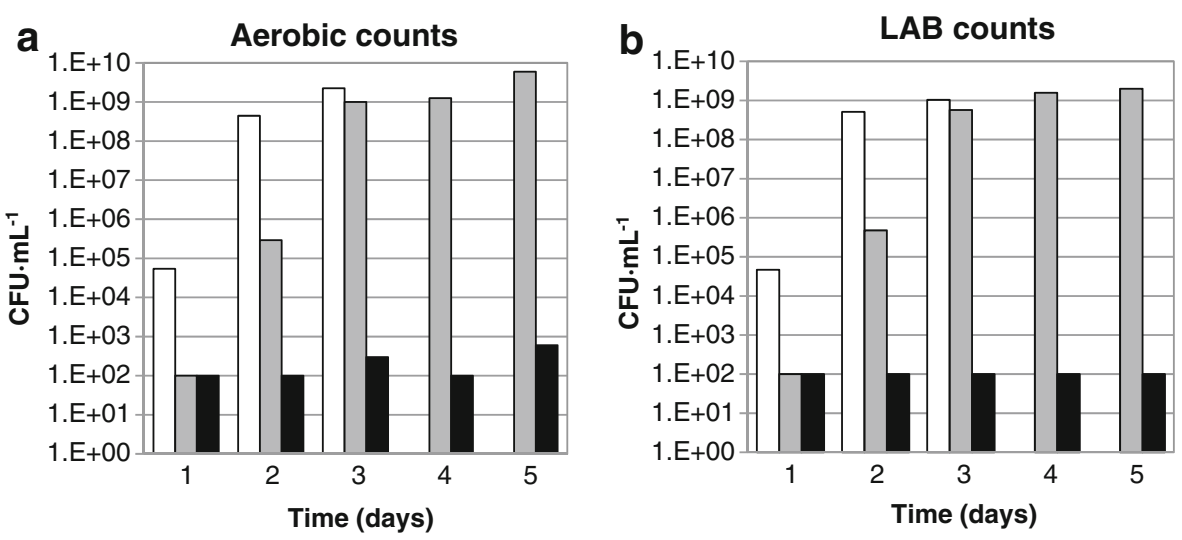

$\square$ Before processing, stored at RT
$\square$ After processing, stored at RT
After processing, stored at $4{ }^{\circ} \mathrm{C}$

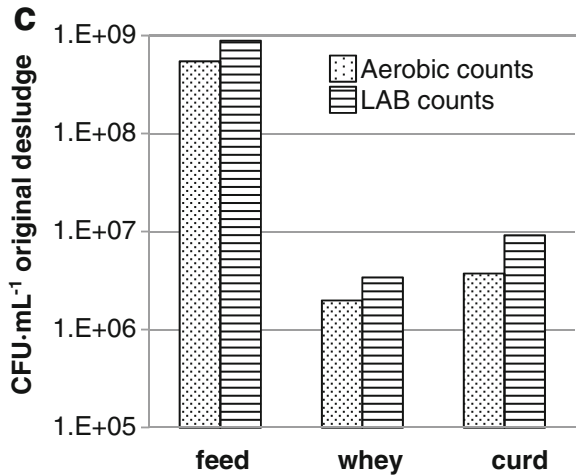

Fig. 6 a, b Shelf-life of bactofuge desludge before (feed) and after processing. Total aerobic bacteria (a) and lactic acid bacteria (b) counts were determined for bactofuge desludge without EPS treatment (white bars) and with EPS treatment, after storage at room temperature (grey bars) or $4{ }^{\circ} \mathrm{C}$ (black bars) for up to 5 days. Processing conditions: 100 bar $\mathrm{CO}_{2} ; 50{ }^{\circ} \mathrm{C} ; 32.5 \mathrm{~W}$ sonicator power; (pulsed) 1 min residence time; energy input of $12 \mathrm{~kJ} \cdot \mathrm{L}^{-1}$. c Partitioning of bacteria into curd and whey fractions following EPS processing. Bactofuge desludge was processed (batch EPS process; 100 bar $\mathrm{CO}_{2} ; 50{ }^{\circ} \mathrm{C} ; 300 \mathrm{~W}$ sonicator power pulsed $1 \mathrm{~s}$ on, $1 \mathrm{~s}$ off; $2 \mathrm{~min}$; energy input of $19 \mathrm{~kJ} \cdot \mathrm{L}^{-1}$ ) and viable aerobic (spotted bars) and LAB (striped bars) determined before processing and after processing in the whey and curd (following stomaching) fractions. Numbers of bacteria are expressed as CFU per millilitre of original desludge sample, taking into consideration the quantity of curd and whey fractions generated during EPS processing 
3 days of storage at room temperature, both untreated and treated bacterial counts were high; the untreated desludge solidified, after which it could not be further assessed.

\subsection{Analysis of curd and whey fractions}

The volume of curd and whey fractions formed after batch processing of bactofuge desludge (100 bar, $50{ }^{\circ} \mathrm{C}, 300 \mathrm{~W}$ power, 1:1 pulse for $1 \mathrm{~min}$ ) were measured. Typically the liquid fraction was between 71 and $77 \%$ with a $22-29 \%$ wet solid fraction. The percentage mass of the dry solid was found to be approximately 5 to $8 \%$ and was determined by drying the wet solid sample in an oven at $25^{\circ} \mathrm{C}$ for 15 consecutive days until there was no mass change. The drying process caused gradual hardening of the sample and resulted in a colour change from white cream to semi-transparent. The solid merged together when drying to form a hard, strong and hollow material of roughly the shape of its container.

The bacterial content of the curd and whey fractions was determined; the curd fraction was stomached to release bacteria (Fig. 6c). Both aerobes and LABs were preferentially partitioned into the curd fraction.

\subsection{Fat and protein content of desludge and processed fractions}

The fat content of the curd and whey fractions obtained after batch processing was determined using the Rose Gottlieb method (Table 2) and compared to values found in the literature (de Wit 2001). Dry solids were obtained after drying at 25 or $70{ }^{\circ} \mathrm{C}$.

Table 2 Fat and protein content of desludge samples before and after batch EPS treatment

\begin{tabular}{|c|c|c|c|c|c|c|}
\hline \multirow[t]{2}{*}{ Sample } & \multirow[t]{2}{*}{ State } & \multicolumn{2}{|c|}{$\begin{array}{l}\text { Fat content } \mathrm{mg} \cdot 100 \mathrm{~mL}^{-1} \\
\text { (liquid) or } \mathrm{mg} \cdot 100 \mathrm{~g}^{-1} \text { (solid) }\end{array}$} & \multicolumn{3}{|c|}{ Protein content $\%$} \\
\hline & & $\begin{array}{l}\text { This } \\
\text { work }\end{array}$ & $\begin{array}{l}\text { Literature } \\
\text { value }\end{array}$ & $\begin{array}{l}\text { This } \\
\text { work }\end{array}$ & $\begin{array}{l}\text { External } \\
\text { lab }\end{array}$ & $\begin{array}{l}\text { Literature } \\
\text { value }\end{array}$ \\
\hline Unprocessed bactofuge desludge & Liquid & 60 & - & 6.89 & 10.55 & - \\
\hline Whey (sample 1) & Liquid & 19.6 & $30-50$ & 0.67 & 1.1 & $0.6-0.62^{\mathrm{a}}$ \\
\hline Whey (sample 2) & Liquid & 16.6 & $30-50$ & 0.53 & 0.7 & $0.6-0.62^{\mathrm{a}}$ \\
\hline Fresh curd of sample 2 & Wet solid & 455.2 & ND & 33.7 & 35.3 & ND \\
\hline Curd of sample 1 dried at $25^{\circ} \mathrm{C}$ & Solid & ND & ND & ND & 77.5 & ND \\
\hline Curd dried at $70^{\circ} \mathrm{C}$ & Solid & ND & ND & ND & 70.95 & ND \\
\hline Unprocessed separator desludge & Liquid & 143.6 & ND & ND & ND & ND \\
\hline Milk $^{\mathrm{b}}$ & Liquid & ND & 4110 & ND & ND & 3.3 \\
\hline
\end{tabular}

All tests processed bactofuge desludge in batch EPS process at $100 \mathrm{bar}, 50{ }^{\circ} \mathrm{C}, 300 \mathrm{~W}$ power for $1 \mathrm{~min}$; samples 1 and 2 are repeat analyses to show reproducibility. Fat content units depend on solid or liquid samples. Fat content compare our data (Rose Gottlieb method) and literature data (de Wit 2001); protein content compare our data (MaxSignal ${ }^{\circledR}$ No-Mel Milk Test Kit), external laboratory data (Kjeldahl method) and literature data (de Wit 2001)

$N D$ not determined

${ }^{a}$ Range of values for casein, lactic acid and cheese whey

${ }^{\mathrm{b}}$ Data for milk from literature (de Wit 2001) 
Protein concentrations of EPS-derived whey fractions determined using the Rose Gottlieb method were comparable to the protein content of casein, lactic acid and cheese whey (de Wit 2001). Protein concentrations of whey samples were also determined by an external laboratory; data were comparable between the two analysis methods. The protein content of cheese is typically between 17 and $42 \%$ with the majority of cheeses being between 20 and 32\%. The fresh wet curd obtained from the EPS process contained $35.3 \%$ protein and so has potential for use as animal feed or other purposes.

The protein content of the bactofuge curds were corrected on a dry basis and are shown in Table 3. The calculation was based on a $60 \%$ moisture content in the fresh curd, $12 \%$ moisture content in the $25{ }^{\circ} \mathrm{C}$ dried curd and $8 \%$ moisture content in the $70{ }^{\circ} \mathrm{C}$ dried curd. The data suggest that drying the processed curd at $70{ }^{\circ} \mathrm{C}$ might damage the protein in the curd. Yellow-brownish areas were seen on the $70{ }^{\circ} \mathrm{C}$ dried curd surface and suggest that the Maillard reaction had occurred in the presence of the water leading to protein damage; its lower protein content agreed with this assumption.

\section{Conclusion}

Elevated pressure sonication (EPS) offers a way to effectively process bactofuge desludge. Pressure alone or sonication alone do not kill bacteria; however, in combination, a 3-log-fold decrease in aerobic bacteria and 3.5-log-fold decrease in lactic acid bacteria can be obtained. Low $\mathrm{CO}_{2}$ pressure (50 bar) can be used to reduce viable aerobic bacteria whereas high $\mathrm{CO}_{2}$ pressure (100 bar) must be used to reduce numbers of lactic acid bacteria. High pressure sonication in the presence of $\mathrm{N}_{2}$ resulted in insignificant cell death. Sonication power as low as 150 or $300 \mathrm{~W}$ can be used to kill aerobic and lactic acid bacteria in a very short treatment time $(<0.5 \mathrm{~min})$. In comparison to HTST of fresh milk, the technology leads to a 10-fold reduction in energy requirement. Comparison with other emerging dairy processing techniques such as high pressure or pulsed electric field treatment is difficult as they have not been applied to desludge treatment; this could form the basis of future work.

The good flow properties of the desludge post-processing meant that this treatment technique has real potential for industries that rely on high volume processing. The treatment of desludge by conventional thermal treatments leads to a latex-like product that cannot flow. The curd fraction could potentially be used as a food or feed product (e.g. cheese or animal feed), or could be used to raise energy by digestion. The whey fraction has value in its own right as a potential source of bioactive peptides. The induced separation can therefore also be seen as a dewatering process of the solid curd fraction. The EPS process thereby generates a value product and the technique has

Table 3 Protein determination of bactofuge curd on dry weight basis

\begin{tabular}{lll}
\hline Sample & Protein \% & Protein \% (dry base) \\
\hline Fresh (wet) curd & 35.3 & 88 \\
$25{ }^{\circ} \mathrm{C}$ dried curd & 77.5 & 88 \\
$70{ }^{\circ} \mathrm{C}$ dried curd & 70.95 & 77 \\
\hline
\end{tabular}


potential to cross over to other dairy products, brewery waste and beverage processing. If the product is considered as a food product, further testing (e.g. for endotoxins in the lysate) and approval is required.

Acknowledgements The authors greatly acknowledge the funding from Innovate UK, Project number 101382, grant number TS/K004018/1

Data access Data sets from the above work may be requested from the authors by email (T.W.Overton@bham.ac.uk or G.A.Leeke@bham.ac.uk).

Open Access This article is distributed under the terms of the Creative Commons Attribution 4.0 International License (http://creativecommons.org/licenses/by/4.0/), which permits unrestricted use, distribution, and reproduction in any medium, provided you give appropriate credit to the original author(s) and the source, provide a link to the Creative Commons license, and indicate if changes were made.

\section{References}

AOAC (2000) In: Horwitz W (ed) Official methods of analysis of AOAC International, 17th edn. Association of Official Analytical Chemists, USA

Bains NS, Leeke GA (2015) Inhibition of microbial and cellular growth in substances. Patent number WO2015052506

Bermúdez-Aguirre D, Barbosa-Cánovas GV (2011) Ultrasound technologies for food and bioprocessing. Food Eng Ser. doi:10.1007/978-1-4419-7472-3_16. Springer

Cenci S, Cox LR, Leeke GA (2014) Ultrasound-induced emulsification of subcritical carbon dioxide and water with and without surfactant as a strategy for enhanced mass transport. Ultrason Sonochem 21:401-408

de Wit JN (2001) Lecturer's handbook on whey and whey products. European Whey Products Association, Brussels

Foster JW, Cowan RM, Maag TA (1962) Rupture of bacteria by explosive decompression. J Bacteriol 83:330334

Fraser D (1951) Bursting bacteria by release of gas pressure. Nature 167:33-34

Geciova J, Bury D, Jelen P (2002) Methods for disruption of microbial cells for potential use in the dairy industry — a review. Int Dairy J 12:541-553

Hemmingsen BB, Hemmingsen EA (1980) Rupture of the cell envelope by induced intracellular gas phase expansion in gas vacuolate bacteria. J Bacteriol 143:841-846

Leeke GA, Santos RC, Seville J, Al-Duri B, Smith CJ, Holmes AB (2005) Solubilities of iodobenzene, phenylboric acid, biphenyl and 4-phenyltoluene in carbon dioxide from the measurements of the relative permittivity. J Chem Eng Data 50:1370-1374

Ortega-Rivas E, Salmerón-Ochoa I (2014) Nonthermal food processing alternatives and their effects on taste and flavor compounds of beverages. Crit Rev Food Sci Nutr. doi:10.1080/10408398.2011.579362

Pereira RN, Vicente AA (2010) Environmental impact of novel thermal and non-thermal technologies in food processing. Food Res Int 43:1935-1943

Sampedro F, Rodrigo M, Martínez A, Rodrigo D, Barbosa-Cánovas GV (2005) Quality and safety aspects of PEF application in milk and milk products. Crit Rev Food Sci Nutr 45:25-47

Wiebe R, Gaddy VL (1939) The solubility in water of carbon dioxide at 50,75 and $100{ }^{\circ} \mathrm{C}$ from 12 to 700 atmospheres. J Am Chem Soc 61:315-318

Wiebe R, Gaddy VL (1940) The solubility of carbon dioxide in water at various temperatures from 12 to $40{ }^{\circ} \mathrm{C}$ and at pressures to 500 atmospheres. Crit Phenom J Am Chem Soc 62:815-817

Wiebe R, Gaddy VL, Heins C (1933) The solubility of nitrogen in water at 50,75 and $100{ }^{\circ} \mathrm{C}$ from 25 to 1000 atmospheres. J Am Chem Soc 55:947-953 